\title{
UJI KINERJA PENGOLAHAN AIR LIMBAH INDUSTRI NATA DE COCO DENGAN PROSES LUMPUR AKTIF
}

\author{
Nusa Idaman Said dan Wahyu Widayat \\ Pusat Teknologi Lingkungan, BPPT, Kawasan Puspiptek, Tangerang Selatan, 15314, Indonesia \\ Email: nusaidamansaid@gmail.com; wdytwahyuw09@gmail.com
}

\begin{abstract}
ABSTRAK
Industri Nata de Coco merupakan merupakan salah satu agroindustri yang dalam proses produksinya menghasilkan air limbah yang bersifat asam dan mengandung konsentrasi polutan organik yang tinggi, terutama air limbah yang berasal dari sisa fermentasi nata. Oleh karena itu, air limbah tersebut harus diolah dengan baik agar tidak mencemari lingkungan. Berdasarkan Peraturan Menteri Lingkungan Hidup Republik Indonesia Nomor 5 Tahun 2014 Tentang Baku Mutu Air Limbah, baku mutu air limbah industri Nata de Coco yang boleh dibuang ke badan air atau saluran umum yakni dengan konsentrasi maksimum COD 150 $\mathrm{mg} / \mathrm{l}, \mathrm{BOD} 75 \mathrm{mg} / \mathrm{l}$, TSS $100 \mathrm{mg} / \mathrm{l}$ dan pH 6-9. Tujuan penelitian ini adalah melakukan uji kinerja pengolahan air limbah industri Nata de Coco yang berlokasi di Gunung Putri, Kabupaten Bogor, menggunakan proses lumpur aktif. Penelitian dilakukan mulai bulan Februari sampai dengan bulan April 2019. Dari hasil penelitian dapat diketahui bahwa air limbah industri Nata de Coco mempunyai $\mathrm{pH}$ yang rendah dengan konsentrasi zat organik (COD) yang tinggi, dapat mencapai lebih dari $5000 \mathrm{mg} / \mathrm{l}$. Perbandingan BOD/COD air limbah berkisar 0,34 sehingga relatif sulit untuk terurai secara biologis. Untuk mengolahan air limbah industri Nata de Coco dengan menggunakan proses lumpur aktif, pH air perlu dinaikan menjadi sekitar 8 agar proses lumpur aktif berjalan optimal. Hasil penelitian menunjukkan bahwa dengan beban COD ratarata $0,56 \mathrm{~kg} \mathrm{COD} / \mathrm{m}^{3}$.hari didapatkan efisiensi rata-rata penghilangan COD sebesar 95,7 \%.
\end{abstract}

Kata Kunci: Air Limbah, Nata de Coco, Lumpur Aktif

\section{PERFORMANCE TEST OF NATA DE COCO INDUSTRIAL WASTE WATER USING ACTIVATED SLUDGE PROCESS}

\author{
Nusa Idaman Said and Wahyu Widayat \\ Center for Environmental Technology, BPPT, Puspiptek Area, South Tangerang, 15314, Indonesia \\ Email: nusaidamansaid@gmail.com ; wdytwahyuw09@gmail.com
}

\begin{abstract}
Nata de Coco industry is one of the agro-industries which in the production process produces acidic wastewater and contains high concentrations of organic pollutants, especially waste water from the remaining fermented nata. Therefore the waste water must be treated properly so as not to pollute the environment. Based on the Regulation of the Minister of Environment of the Republic of Indonesia Number 5 of 2014 concerning Waste Water Quality Standards, the quality standards of Nata de Coco industrial wastewater which may be disposed of into water bodies or public channels namely maximum concentration of COD $150 \mathrm{mg} / \mathrm{l}, \mathrm{BOD} 75 \mathrm{mg} / \mathrm{l}, \mathrm{TSS} 100 \mathrm{mg} / \mathrm{l}$ and $\mathrm{pH}$ 6-9. The research objective was to conduct a performance test of Nata de Coco industrial wastewater treatment located in Gunung Putri, Bogor Regency, using an activated sludge process. The study was conducted from February to April 2019. From the results of the study it can be seen that the Nata de Coco industrial wastewater has a low $\mathrm{pH}$ with a high concentration of organic matter (COD), which can reach more than $5000 \mathrm{mg} / \mathrm{l}$. Comparison of BOD/COD wastewater is around 0.34 so it is relatively difficult to biodegrade. To process Nata de Coco industrial wastewater using the activated sludge process, the $\mathrm{pH}$ of the water needs to be increased to around 8 so that the activated sludge process runs optimally. The results showed that with an average COD loading of $0.56 \mathrm{~kg} \mathrm{COD} / \mathrm{m}^{3}$ per day, the average efficiency of COD removal was $95.7 \%$.
\end{abstract}

Keywords: Wastewater, Nata de Coco, Activated Sludge 


\section{PENDAHULUAN}

Industri nata de coco merupakan salah satu industri di Indonesia memanfaatkan bahan baku buah kelapa. Buah kelapa terdiri dari kulit luar, sabut, tempurung, kulit daging (testa), daging buah, air kelapa dan lembaga. Air kelapa dapat dimanfaatkan sebagai bahan baku dalam pembuatan nata de coco. Akhir-akhir ini pemanfaatan bahan baku air kelapa untuk argoindustri nata de coco mengalami peningkatan. Perkembangan jumlah argoindustri nata de coco akan mengakibatkan semakin besarnya limbah yang dihasilkan dari industri ini (Hakimi dan Daddy, 2006).

Industri nata de coco merupakan salah satu agroindustri yang dalam proses produksinya menghasilkan limbah baik itu berupa limbah cair, maupun limbah padat. Limbah yang dihasilkan dari aktivitas industri nata de coco sulit dihindari, terutama untuk limbah air yang digunakan dalam proses perendaman. Limbah air ini bersifat asam karena mengandung asam asetat dalam konsentrasi tinggi (Pambayun, 2002 : 32). Limbah cair sisa fermentasi yang memiliki bau tidak sedap ini akan meyebabkan pencemaran air karena masih terkandung banyak bahan organik didalamnya. Pencemaran bahan organik ke perairan akan mengakibatkan tergangunya kualitas air sedangkan bau yang tidak sedap dari limbah cair sisa fermentasi nata de coco terjadi akibat adanya kondisi anaerobik yang menghasilkan karbon dioksida dan hidrogen sulfida.

Proses utama dalam pembuatan Nata de Coco meliputi rangkaian proses antara lain: a) persiapan medium; b) persiapan starter; c) proses fermentasi; penghilangan asam (deasidifikasi); dan e) pengawetan. Setelah proses fermentasi, nata dipanen dan dipotongpotong sesuai ukuran yang diharapkan, selanjutnya direndam di dalam air bersih dengan memberikan air secara terus menerus sampai rasa asamnya hilang, kemudian direbus selama kurang lebih 30 menit. Setelah itu ditiriskan,kemudian dicampur dengan air gula atau sirup dengan rasa tertentu, dan selanjutnya dikemas dan disterilkan (Saragih, 2014). Secara umum diagram proses pembuatan Nata de coco dapat dilihat seperti pada Gambar 1.

Beberapa faktor yang mempengaruhi pembuatan nata de coco antara lain adalah: sumber gula, suhu fermentasi, tingkat keasaman medium, lama fermentasi, serta aktifitas bakteri (Alaban, 1962). Nata de coco dibentuk oleh mikro organisme Acetobacter Xylinum. Pembentukan nata de coco terjadi karena proses pengambilan glukosa dari larutan gula atau gula dalam air kelapa oleh sel-sel Acetobacter Xylinum (Suhardiyono, 1988)

Di dalam industri nata de coco, air limbah dihasilkan dari beberapa sumber: 1) air Limbah panen yaitu air limbah yang berasal dari sisa proses fermentasi nata de coco yang tidak jadi, 2) air limbah pencucian nata de coco yaitu air limbah pencucian nata de coco awal, 3) air limbah bilas akhir yaitu air pencucian nata de coco akhir, 4) air Limbah pencucian baki (tray) yaitu air limbah yang dihasilkan dari proses pencucian baki tempat pembuatan nata de coco.

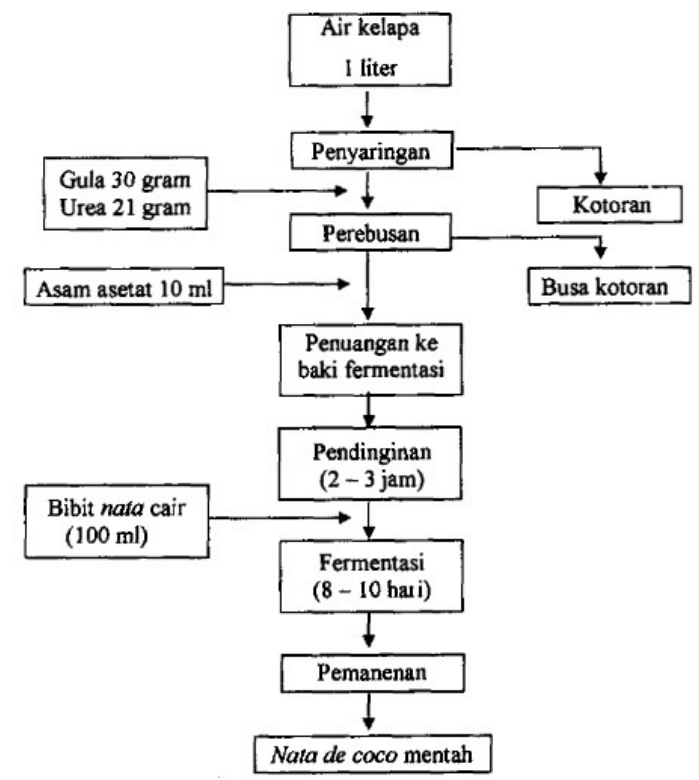

Gambar 1. Diagram proses pembuatan Nata De Coco (Saragih, 2004)

Air limbah panen jumlahnya relatif sedikit dengan konsentrasi zat organik yang tinggi yakni konsentrasi COD dapat mencapai $30.000 \mathrm{mg} / \mathrm{l}$, dengan $\mathrm{pH}$ antara 3 - 4. Sedangkan gabungan air limbah yang yang berasal dari proses yang lainnya mempunyai konsentrasi COD yang relatif lebih rendah yakni berkisar antara 1500 $6000 \mathrm{mg} / \mathrm{l}$. Dengan demikan, air limbah industri nata de coco jika tidak diolah dengan baik akan sangat berpotensi menyebabkan pencemaran lingkungan, khususnya pencenaran badan air.

Berdasarkan Peraturan Menteri Lingkungan Hidup Republik Indonesia Nomor 5 Tahun 2014 Tentang Baku Mutu Air Limbah: Lampiran XVII Baku Mutu Air Limbah Bagi Usaha Dan/Atau Kegiatan Pengolahan Kelapa, maka baku mutu air limbah industri nata de coco yang boleh dibuang ke badan air atau saluran umum yakni konsentrasi maksimum COD 150 mg/l, BOD 75 mg/l, TSS 100 mg/l dan pH 6-9.

Makalah ini membahas tentang hasil uji kinerja pengolahan air limbah industri nata de 
coco dengan proses lumpur aktif di salah satu industri nata de coco yang berlokasi di Gunung Putri, Kabupaten Bogor.

\section{PENGOLAHAN AIR LIMBAH DENGAN PROSES LUMPUR AKTIF}

Ada berbagai macam desain pengolahan air limbah dengan lumpur aktif, tetapi pada prinsipnya semua proses lumpur aktif terdiri dari tiga komponen utama: 1) sebuah bak atau tangki aerasi yang berfungsi sebagai reaktor biologis, 2) sebuah bak atau tangki pengendapan akhir (final clarifier) untuk pemisahan padatan dari lumpur aktif dan air limbah yang telah diolah, 3) peralatan sirkulasi lumpur aktif (return activated sludge, RAS) yang berfungsi untuk mentransfer lumpur aktif yang mengendap di bak pengendap akhir ke influen bak aerasi (Rainier. et.al., 2015).

Salah satu karakteristik penting di dalam proses lumpur aktif adalah adanya resirkulasi biomasa dalam jumlah yang besar dari bak pengendap alkhir ke bak aerasi. Hal ini menyebabkan waktu tinggal cel rata-rata (umur lumpur) menjadi lebih besar dibandingkan dengan waktu tinggal hidroliknya (Sterrit and Lester, 1988). Dengan adanya resirkulasi biomasa dalam jumlah yang besar tersebut dapat menjaga mikrooraganisme mengoksidasi senyawa organik dengan efektif dalam waktu yang relatif singkat (Bitton, 1994).

Udara atmosfer dihembuskan ke dalam air limbah di dalam bak aerasi. Dengan adanya oksigen di dalam air limbah maka polutan organik akan diuraikan oleh mikroorganisme yang ada di dalam air limbah dan diubah menjadi biomassa atau flok biologis yang disebut lumpur aktif.

Campuran air limbah dan biomassa di dalam bak aerasi umumnya dikenal sebagai mixed liquor suspended solids (MLSS). Dengan proses lumpur aktif sebagian besar polutan organik yang ada di dalam influen air limbah akan diuraikan secara biologis dan sebagian secara kimia di dalam bak aerasi. Efisiensi penghilangan dipengaruhi oleh beberapa faktor yang berbeda misalnya waktu tinggal hidrolik (hydraulic residence time, HRT) di dalam bak aerasi, yang didefinisikan sebagai volume bak aerasi dibagi dengan debit air limbah yang masuk. Faktor lain adalah beban influen yakni konsentrasi zat organik (BOD, COD), konsentrasi amoniak, suplai udara atau oksigen, pengaruh suhu dan lainnya.

Efluen dari bak aerasi selanjutnya dilairkan ke bak pengendap akhir. Di dalam bak pengendap akhir lumpur aktif diendapkan atau dipisahkan dari air limbah yang telah diolah. Air jernih yang ada di bagian atas bak pengendap (supernatant) merupakan air olahan dan dibuang ke saluran umum, sedangkan lumpur aktif yang mengendap di dasar bak pengendap akhir dikembalikan lagi ke bagian inlet bak aerasi untuk menguraikan polutan yang ada didalam air limbah. Jumlah lumpur yang disirkulasi diatur sedemikian rupa agar didapatkan konsentrasi MLSS seperti yang diharapkan agar proses dapat berjalan dengan sempurna.

$\mathrm{Di}$ dalam penguraian polutan secara biologis, sebagian substrat akan digunakan untuk pertumbuhan biomassa sehingga akan terjadi akumulasi konsentrasi biomassa (MLSS) di dalam bak areasi. Oleh karena itu, untuk mendapatkan konsentrasi MLSS sesuai dengan yang diharapkan maka kelebihan lumpur aktif harus dibuang dan dialirkan ke unit pengolahan lumpur (sludge treatment) baik secara anaerobik atau aerobik sebelum dibuang. Proses pengolahan air limbah sistem lumpur aktif standar secara sederhana dapat dilihat pada Gambar 2 (JSWA, 1984).

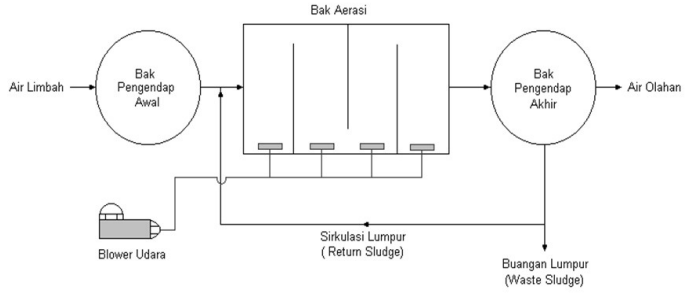

Gambar 2. Sistem lumpur aktif standar atau konvensional (JSWA, 1984).

Keunggulan proses lumpur aktif ini adalah dapat mengolah air limbah dengan beban organik yang besar sehingga tidak memerlukan tempat yang besar. Selain itu, proses lumpur aktif memiliki keunggulan dapat menghasilkan air olahan dengan kualitas yang baik dengan biaya operasi dan pemeliharaan yang wajar (Bhargava, 2016).

Variabel perencanan (design variabel) yang umum digunakan dalam proses pengolahan air limbah dengan sistem lumpur aktif (Davis dan Cornwell, 1985; Verstraete dan van Vaerenbergh, 1986) di jelaskan dalam subbab selanjutnya.

\subsection{Beban Organik (BOD/COD Loading Rate Atau Volumetric Loading Rate)}

Beban BOD adalah jumlah massa BOD di dalam air limbah yang masuk (influent) dibagi dengan volume reaktor atau bak aerasi (JSWA, 1984; Ebie and Ashidate, 1992). Beban BOD dapat dihitung dengan rumus sebagai berikut:

$$
\text { Beban Organik }=\frac{\mathrm{Q} \times \mathrm{S}_{0}}{\mathrm{~V}} \mathrm{~kg} / \mathrm{m}^{3} \text {.hari }
$$

Di mana : 
$\mathrm{Q}=$ Debit air limbah yang masuk ( $\mathrm{m}^{3} /$ hari).

$\mathrm{S}_{0}=$ Konsentrasi BOD/COD di dalam air limbah yang masuk $\left(\mathrm{kg} / \mathrm{m}^{3}\right)$.

$\mathrm{V}=$ Volume reaktor $\left(\mathrm{m}^{3}\right)$.

Untuk proses lumpur aktif standar beban organik (beban BOD) berkisar antara 0,3-0,8 $\mathrm{kg} / \mathrm{m}^{3}$. hari)

\subsection{Mixed-liqour suspended solids (MLSS)}

Isi di dalam bak aerasi pada proses pengolahan air limbah dengan sistem lumpur aktif disebut sebagai mixed liqour yang merupakan campuran antara air limbah dengan biomassa mikroorganisme serta padatan tersuspensi lainnya. MLSS adalah jumlah total dari padatan tersuspensi yang berupa material organik dan mineral, termasuk di dalamnya adalah mikroorganisme. MLSS ditentukan dengan cara menyaring lumpur campuran dengan kertas saring (filter), kemudian filter dikeringkan pada temperatur $105^{\circ} \mathrm{C}$, dan berat padatan dalam contoh ditimbang.

\subsection{Mixed-liqour volatile suspended solids (MLVSS)}

Porsi material organik pada MLSS diwakili oleh MLVSS, yang berisi material organik bukan mikroba, mikroba hidup dan mati, dan hancuran sel (Nelson dan Lawrence, 1980). MLVSS diukur dengan memanaskan terus sampel filter yang telah kering pada $600-650{ }^{\circ} \mathrm{C}$, dan untuk proses lumpur aktif yang bauk nilai MLVSS mendekati $65-75 \%$ dari $M L S S$.

\subsection{Food-To-Microorganism Ratio Atau Food-To Mass Ratio Disingkat F/M Ratio}

Parameter ini menujukkan jumlah zat organik (BOD) yang dihilangkan dibagi dengan jumlah massa mikroorganisme di dalam bak aerasi atau reaktor. Besarnya nilai $F / M$ ratio umunya ditunjukkan dalam kilogram BOD per kilogram MLLSS per hari (Curds dan Hawkes, 1983; Nathanson, 1986). F/M dapat dihitung dengan menggunakan rumus sebagai berikut:

Di mana:

$$
F / M=\frac{Q\left(S_{0}-S\right)}{M L S S \times V}
$$

$\mathrm{Q}=$ Laju alir limbah $\mathrm{m}^{3}$ per hari.

$\mathrm{S}_{0}=$ Konsentrasi BOD di dalam air limbah yang masuk ke bak areasi (reaktor) $\left(\mathrm{kg} / \mathrm{m}^{3}\right)$.

$\mathrm{S}=$ Konsentrasi BOD di dalam efluent $\left(\mathrm{kg} / \mathrm{m}^{3}\right)$.

$$
\begin{aligned}
\text { MLSS }= & \text { Mixed liquor suspended solids } \\
& \left(\mathrm{kg} / \mathrm{m}^{3}\right) . \\
= & \text { Volume reaktor atau bak aerasi } \\
& \left(\mathrm{m}^{3}\right) .
\end{aligned}
$$

Rasio F/M dapat dikontrol dengan cara mengatur laju sirkulasi lumpur aktif dari bak pengendapan akhir yang disirkulasi ke bak aerasi. Lebih tinggi laju sirkulasi lumpur aktif lebih tinggi pula rasio F/M-nya. Untuk pengolahan air limbah dengan sistem lumpur aktif konvensional atau standar, rasio $F / M$ adalah 0,2 - 0,5 kg BOD 5 per $\mathrm{kg} M L S S$ per hari, tetapi dapat lebih tinggi hingga 1,5 jika digunakan oksigen murni (Hammer, 1986). Rasio $F / M$ yang rendah menujukkan bahwa mikroorganisme dalam tangki aerasi dalam kondisi lapar, semakin rendah rasio $\mathrm{F} / \mathrm{M}$ pengolah limbah semakin efisien.

\subsection{Hidraulic Retention Time (HRT)}

Waktu tinggal hidraulik (HRT) adalah waktu rata-rata yang dibutuhkan oleh larutan influen masuk dalam tangki aerasi untuk proses lumpur aktif; nilainya berbanding terbalik dengan laju pengenceran (dilution rate, D) (Sterritt dan Lester, 1988).

Di mana :

$$
\mathrm{HRT}=1 / \mathrm{D}=\mathrm{V} / \mathrm{Q}
$$

$$
\begin{aligned}
\mathrm{V}= & \text { Volume reaktor atau bak aerasi }\left(\mathrm{m}^{3}\right) . \\
\mathrm{Q}= & \text { Debit air limbah yang masuk ke } \\
& \text { dalamTangki aerasi }\left(\mathrm{m}^{3} / \mathrm{jam}\right) . \\
\mathrm{D}= & \text { Laju pengenceran }\left(\mathrm{jam}^{-1}\right) .
\end{aligned}
$$

\subsection{Ratio Sirkulasi Lumpur (Hidraulic Recycle Ratio, HRT)}

Ratio sirkulasi lumpur adalah perbandingan antara jumlah lumpur yang disirkulasikan ke bak aerasi dengan jumlah air limbah yang masuk ke dalam bak aerasi.

\subsection{Umur lumpur (Sludge Age)}

Istilah ini sering disebut waktu tinggal rata-rata cel (mean cell residence time). Parameter ini menujukkan waktu tinggal ratarata mikroorganisme dalam sistem lumpur aktif. Jika HRT memerlukan waktu dalam jam, maka waktu tinggal sel mikroba dalam bak aerasi dapat dalam hitungan hari. Parameter ini berbanding terbalik dengan laju pertumbuhan mikroba. Umur lumpur dapat dihitung dengan rumus sebagai berikut (Hammer, 1986; Curds dan Hawkes, 1983):

$$
\text { Umur Lumpur (Hari) }=\frac{M L S S \times V}{S S_{e} \times Q_{e}+S S_{w} \times Q_{w}}
$$


Di mana:

$$
\begin{aligned}
\text { MLSS }= & \text { Mixed liquor suspended solids } \\
& (\mathrm{mg} / \mathrm{l}) . \\
\mathrm{V}= & \text { Volume bak aerasi }\left(\mathrm{m}^{3}\right) . \\
\mathrm{SS}_{\mathrm{e}}= & \text { Padatan tersuspensi dalam } \\
& \text { effluent (mg/l). } \\
\mathrm{SS}_{\mathrm{w}}= & \text { Padatan tersuspensi dalam air } \\
& \text { limbah }(\mathrm{mg} / \mathrm{l}) \\
\mathrm{Q}_{\mathrm{e}}= & \text { Laju effluent limbah }\left(\mathrm{m}^{3} / \text { hari }\right) \\
\mathrm{Q}_{\mathrm{w}}= & \text { Laju influent limbah }\left(\mathrm{m}^{3} / \text { hari }\right) .
\end{aligned}
$$

Umur lumpur dapat bervariasi antara 5 15 hari untuk sistem lumpur aktif konvensional. Pada musim dingin dapat menjadi lebih lama dibandingkan pada musim panas (U.S. EPA, 1987). Parameter penting yang mengendalikan operasi lumpur aktif adalah beban organik atau beban BOD, suplay oksigen, dan pengendalian dan operasi bak pengendapan akhir. Bak pengendapan akhir ini mempunyai dua fungsi yakni untuk penjernihan (clarification) dan pemekatan lumpur (thickening).

Campuran air limbah dan lumpur (mixed liqour) dipindahkan dari tangki aerasi ke bak pengendapan akhir. Di dalam bak pengendapan akhir ini, lumpur yang mengandung mikroorganisme yang masih aktif dipisahkan dari air limbah yang telah diolah. Sebagian dari lumpur yang masih aktif ini dikembalikan ke bak aerasi dan sebagian lagi dibuang dan dipindahkan ke pengolahan lumpur. Sel - sel mikroba terjadi dalam bentuk agregat atau flok, densitasnya cukup untuk mengendap dalam tangki penjernih.

Pengendapan lumpur tergantung rasio F/M dan umur lumpur. Pengendapan yang baik dapat terjadi jika lumpur mikroorganisme berada dalam fase endogeneous, yang terjadi jika karbon dan sumber energi terbatas dan jika pertumbuhan bakteri rendah. Pengendapan lumpur yang baik dapat terjadi pada rasio $F / M$ yang rendah (contoh : tingginya konsentrasi MLSS). Sebaliknya, rasio $F / M$ yang tinggi mengakibatkan pengendapan lumpur yang buruk.

Dalam air limbah domestik, rasio $F / M$ yang optimum antara 0,2 - 0,5 (Gaudy, 1988 ; Hammer, 1986). Rata-rata waktu tinggal sel yang diperlukan untuk pengendapan yang efektif adalah 3 - 4 hari (Metcalf dan Eddy, 1991). Pengendapan yang tidak baik dapat terjadi akibat gangguan yang tiba-tiba pada parameter fisik (suhu dan $\mathrm{pH}$ ), kekurangan makanan (contoh $\mathrm{N}$, suhu, mikro-nutrien), dan kehadiran zat racun (seperti logam berat) yang dapat menyebabkan hancurnya sebagian flok yang sudah terbentuk (Chudoba, 1989). Untuk operasi rutin, operator harus mengukur laju pengendapan lumpur dengan menentukan indeks volume lumpur (sludge volume index, SVI) (Forster dan Johnston, 1987).

Cara konvensional untuk mengamati kemampuan pengendapan lumpur adalah dengan menentukan Indeks Volume Sludge (Sludge Volume Index = SVI). Caranya adalah sebagai berikut: campuran lumpur dan air limbah (mixed liquor) dari bak aerasi dimasukkan ke dalam silinder kerucut volume 1 liter dan dibiarkan selama 30 menit. Volume sludge dicatat. SVI adalah menujukkan besarnya volume yang ditempati 1 gram lumpur (sludge). SVI dapat dihitung menggunakan rumus sebagai berikut :

$$
\begin{aligned}
& \text { SVI }(\mathrm{ml} / \mathrm{g})= \frac{\text { SV } \times 1000}{\text { MLSS }} \text { mililiter per gram } \\
& \begin{array}{c}
\text { Dimana: } \\
\text { SV }=
\end{array} \text { Volume endapan lumpur di dalam } \\
& \begin{array}{l}
\text { silinder kerucut setelah } 30 \text { menit } \\
\text { pengendapan (ml). }
\end{array} \\
& M L S S= \text { adalah mixed liqour suspended } \\
& \text { solid }(\mathrm{mg} / \mathrm{l}) .
\end{aligned}
$$

Di dalam unit pengolahan air limbah dengan sistem lumpur aktif konvensional dengan $M L S S<3500 \mathrm{mg} / \mathrm{l}$ nilai SVI yang normal berkisar antara $50-150 \mathrm{ml} / \mathrm{g}$.

\section{METODA PENELITIAN}

\subsection{Lokasi Penelitian}

Loksi penelitian adalah di pabrik Nata de Coco PT Kara Santan Pratama yang berlokasi di Gunung Putri, Kabupaten Bogor, Jawa Barat.

\subsection{Analisa Kualitas Air}

Analisa COD dilakukan dengan menggunakan Instrumen spektrofotometer $\mathrm{HACH}$ DR2800, dan COD Reactor Hanna Instruments $\mathrm{HI} 839800$.

\subsection{Proses Pengolahan Air Limbah Industri Nata De Coco}

Pengolahan air limbah industri Nata De Coco dengan proses lumpur aktif konvensional (standar) terdiri dari bak pengendap awal, bak aerasi dan bak pengendap akhir. Air limbah yang berasal dari proses produksi ditampung ke dalam bak penampung air limbah. Bak penampung ini berfungsi sebagai bak pengatur debit air limbah serta dilengkapi dengan saringan kasar untuk memisahkan kotoran yang besar. Selanjutnya, air limbah dalam bak penampung di pompa ke bak pemisah minyak dan selanjutnya dialirkan ke bak ekualisasi. Dari bak ekualisasi, air limbah dipompa ke bak pengendap awal, selanjutnya air limpasan dari 
bak pengendap awal dialirkan ke bak aerasi sambil dihembus dengan udara. Dari bak aerasi, air limbah dialirkan ke bak pengendap akhir dan air limpasan dari bak pengendap akhir dialirkan ke bak penampung antara untuk diproses lebih lanjut dengan proses kimia fisika.

Bak pengendap awal berfungsi untuk menurunkan padatan tersuspensi (Suspended Solids). Air limpasan dari bak pengendap awal dialirkan ke bak aerasi secara gravitasi. Di dalam bak aerasi ini air limbah dihembus dengan udara sehingga mikro organisme yang ada akan menguraikan zat organik yang ada dalam air limbah. Energi yang didapatkan dari hasil penguraian zat organik tersebut digunakan oleh mikrorganisme untuk proses pertumbuhannya. Dengan demikian didalam bak aerasi tersebut akan tumbuh dan berkembang biomasa dalam jumlah yang besar. Biomasa atau mikroorganisme inilah yang akan menguaraikan senyawa polutan yang ada di dalam air limbah. Dari bak aerasi, air dialirkan ke bak pengendap akhir. Di dalam bak ini lumpur aktif yang mengandung masa mikroorganisme diendapkan dan dipompa kembali ke bagian inlet bak aerasi dengan pompa sirkulasi lumpur atau menggunakan pompa air lift (air lift pump).

Air limpasan (over flow) dari bak pengendap akhir dialirkan ke bak klorinasi dan selanjutnya dibuang ke saluran umum. Surplus lumpur dari bak pengendap awal maupun akhir ditampung ke dalam bak penampung atau pemekat lumpur, selanjutnya endapan lumpur dipompa ke bak pengering lumpur, sedangkan air resapannya ditampung kembali di bak penampung air limbah. Diagram pengolahan air limbah industri Nata De Coco dengan proses lumpur aktif dapat dilihat pada Gambar 3.

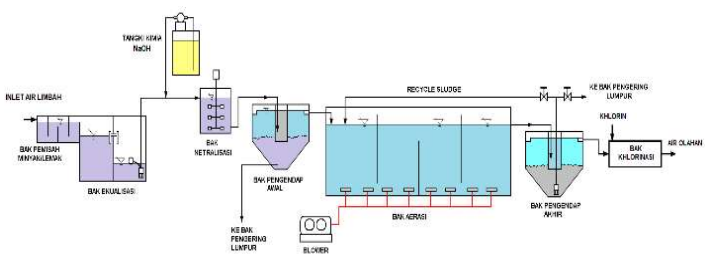

Gambar 3. Diagram pengolahan air limbah industri Nata de Coco dengan proses lumpur aktif.

\subsection{Periode Uji Kinerja}

Penelitian dilakukan mulai bulan Februari sampai dengan bulan April 2019. Periode bulan Februari merupakan masa penumbuhan mikroba di dalam bak aerasi sampai kinerja IPAL mulai stabil. Periode Maret-April 2019 adalah periode dimana kinerja IPAL dianggap sudah stabil.

\subsection{Spesifikasi Teknis IPAL Lumpur Aktif Industri Nata de Coco}

Spesifikasi unit IPAL utama yang digunakan untuk pengolahan air limbah industri Nata de Coco ynag digunakan selama penelitian adalah sebagai berikut:

\begin{tabular}{|c|c|}
\hline \multicolumn{2}{|l|}{ Bak Pengendap Awal } \\
\hline Panjang & $400 \mathrm{~cm}$ \\
\hline Lebar & $400 \mathrm{~cm}$ \\
\hline Kedalaman efektif & $300 \mathrm{~cm}$ \\
\hline Tinggi Ruang Bebas & $50 \mathrm{~cm}$ \\
\hline Bahan & : Beton bertulang K250 \\
\hline Jumlah & : 1 unit \\
\hline Volume efektif & $: 48 \mathrm{~m}^{3}$ \\
\hline \multicolumn{2}{|l|}{ Bak Aerasi } \\
\hline Panjang & $: 1200 \mathrm{~cm}$ \\
\hline Lebar & $: 800 \mathrm{~cm}$ \\
\hline Kedalaman efektif & : $350 \mathrm{~cm}$ \\
\hline Tinggi Ruang Bebas & : $50 \mathrm{~cm}$ \\
\hline Bahan & : Beton bertulang \\
\hline Jumlah & : 1 unit \\
\hline Volume efektif & : $383 \mathrm{~m}^{3}$ \\
\hline Keterangan & $\begin{array}{l}\text { : Jumlah ruang bak } \\
\text { aerasi di bagi menjadi } \\
\text { enam ruang masing } \\
\text { dengan ukuran }(4 \mathrm{~m} x\end{array}$ \\
\hline & $\begin{array}{l}4 \mathrm{~m} \times 3,5 \mathrm{~m} \text { ) dengan } \\
\text { aliran berurutan (seri). }\end{array}$ \\
\hline
\end{tabular}

$\begin{array}{ll}\text { Blower Udara Untuk Proses Lumpur Aktif } \\ \text { Tipe } & \text { : Root Blower } \\ \text { Merk } & : \text { Shoufu } \\ \text { Kapasitas } & : 8,77 \mathrm{~m}^{3} / \mathrm{menit} \\ \text { Bahan } & : \text { Cast iron } \\ \text { Total head } & : 3500-4000 \mathrm{~mm} \text { aqua } \\ \text { Daya Listrik } & : 8,6 \mathrm{Kw}, 380 \text { Volt, } 3 \\ & \text { phase, } 50 \mathrm{~Hz} \\ \text { RPM } & : 1500 \mathrm{Rpm} \\ \text { Jumlah } & : 2 \quad \text { unit (operasi } \\ & \text { bergantian) } \\ \text { Perlengkapan } & : \text { Dilengkapi dengan } \\ & \text { silencer, ball valve dan } \\ & \text { check valve. }\end{array}$

Difuser Udara (Untuk Proses Lumpur Aktif)

Tipe : Fine Bubbles Difucer

Size $\quad: 250 \mathrm{~mm}$

Connection Diameter : $3 / 4$ “

Material : Plastik single membrane

Jumlah : 96 buah. Bak Aerasi di bagi menjadi 6 Ruang dan tiap ruang dilengkapi dengan 16 difuser

Bak Pengendap Akhir

Panjang : $400 \mathrm{~cm}$ 


\begin{tabular}{|c|c|}
\hline Lebar & $400 \mathrm{~cm}$ \\
\hline Kedalaman efektif & $: 300 \mathrm{~cm}$ \\
\hline Tinggi Ruang Bebas & $\begin{array}{l}50 \mathrm{~cm} \text { (disesuaikan } \\
\text { dengan kondisi lokasi) }\end{array}$ \\
\hline Baha & Beton bertulang K250 \\
\hline Jumlah & : 1 unit \\
\hline Volume efektif & $: 48 \mathrm{~m}^{3}$ \\
\hline \multicolumn{2}{|c|}{ Pompa Sirkulasi Lumpur } \\
\hline Tipe & $\begin{array}{l}\text { : Pompa celup } \\
\text { submersible }\end{array}$ \\
\hline Merk & : HCP atau yang setara \\
\hline Kapasitas & : $0,1-0,22 \mathrm{~m} 3 /$ menit \\
\hline Bahan & : Stainless Steel \\
\hline Total head & $: 8 \mathrm{~m}$ \\
\hline Daya Listrik & : $0,5 \mathrm{~kW}, 220$ Volt \\
\hline Diameter Outlet & 2 \\
\hline Jumlah & 2 unit (satu unit \\
\hline & $\begin{array}{l}\text { dan } 1 \text { unit } \\
\text { cadangan) }\end{array}$ \\
\hline
\end{tabular}

Sket gambar konstruksi IPAL lumpur aktif yang digunakan untuk mengolah air limbah industri Nata de Coco dapat dilihat seperti pada Gambar 4 sampai dengan Gambar 6, sedangkan foto IPAL lumpur aktif yang sedang beroperasi dapat dilihat pada Gambar 7 sampai dengan Gambar 9.

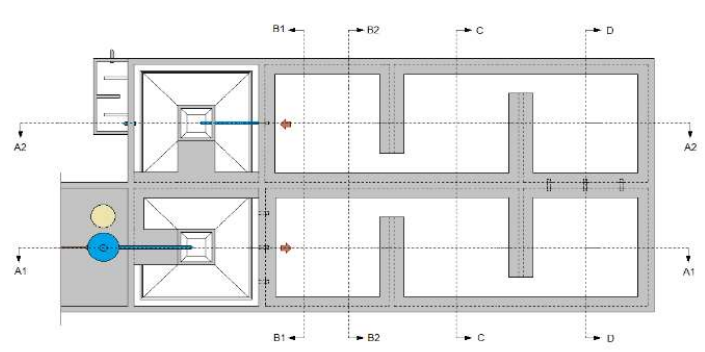

Gambar 4. Bak Pengendap Awal, Bak Areasi Dan Bak Pengendap Akhir-Potongan.

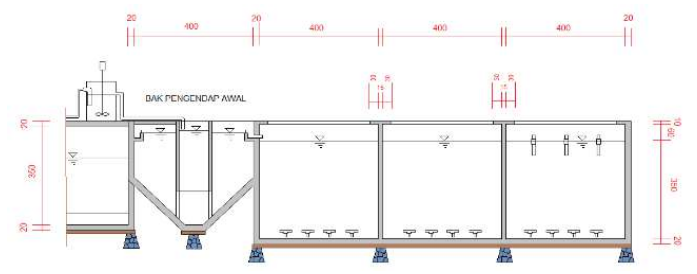

Gambar 5. Bak Pengendapan Awal Dan Bak Aerasi - Potongan Melintang A1-A1.

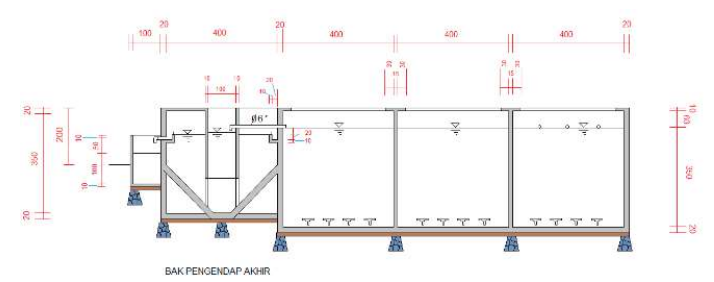

Gambar 6: Bak Aerasi Dan Bak Pengendapan Akhir - Potongan Melintang A2-A2.

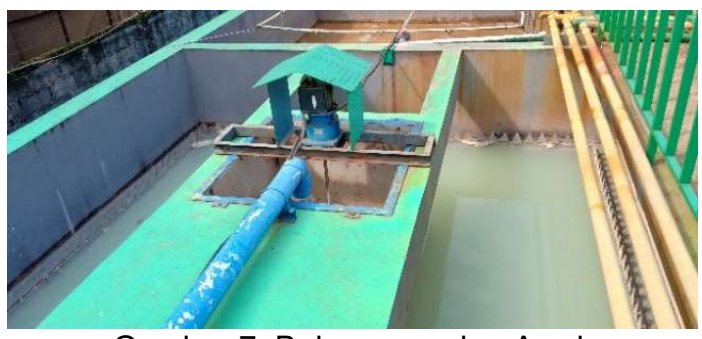

Gambar 7. Bak pengendap Awal.

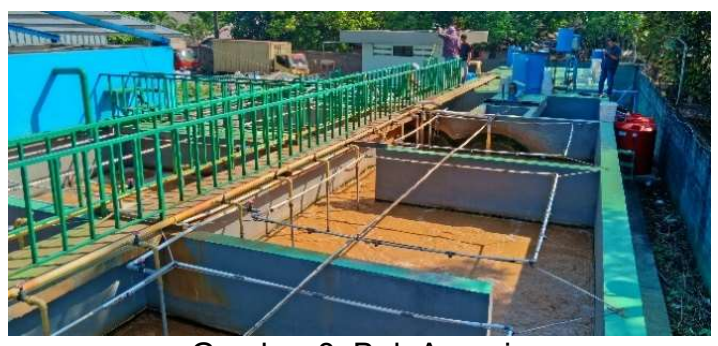

Gambar 8. Bak Aerasi.

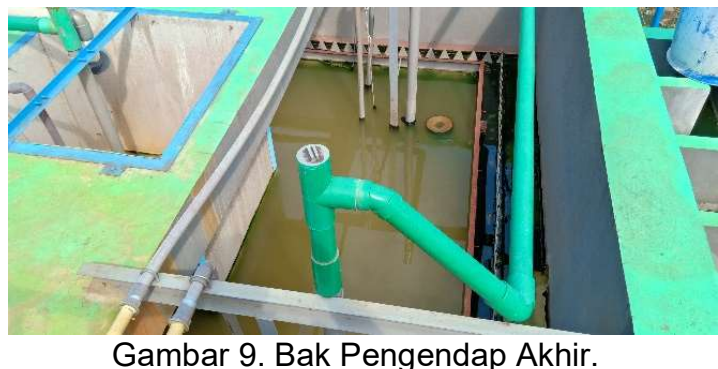

\section{HASIL DAN PEMBAHASAN}

\section{1 pH Air Limbah}

Di dalam uji kinerja IPAL lumpur aktif di industri Nata de Coco yang telah dilakukan, air limbah panen hasil fermentasi Nata tidak dimasukkan ke dalam IPAL karena konsentrasi COD nya terlalu tinggi, sedangkan air limbah yang lain dikumpulkan di bak penampung dan selanjutnya diopma ke bak pemisah lemak dan overflownya masuk ke bak ekualisasi. Oleh karena $\mathrm{pH}$ air limbah rendah yakni sekitar 4-5, maka dilakukan pembubuhan larutan $\mathrm{NaOH}$ secara bertahap yakni sebelum masuk ke bak pemisah lemak, dan sebelum masuk ke bak pengendap awal. $\mathrm{pH}$ air limbah yang masuk ke bak pengendap awal dinaikkan menjadi sekitar 8.

Dari hasil uji kinerja IPAL dari bulan Pebruari sampai dengan bulan April 2019, pH air limbah di bak ekualisasi masih berfluktuasi $\mathrm{pH}$, sedangkan $\mathrm{pH}$ air limbah yang masuk ke bak aerasi dan $\mathrm{pH}$ air di outlet atau efluen IPAL relatif sama yakni sekitar $\mathrm{pH}$ 8. Uji kinerja prioda bulan Pebruari merupakan proses penumbuhan mikroba di dalam bak aerasi (proses seeding). Garfik pH air limbah di bak ekualisasi, $\mathrm{pH}$ inlet 
bak aerasi dan dan $\mathrm{pH}$ outlet IPAL dapat dilihat sepeti pada Gambar 10.

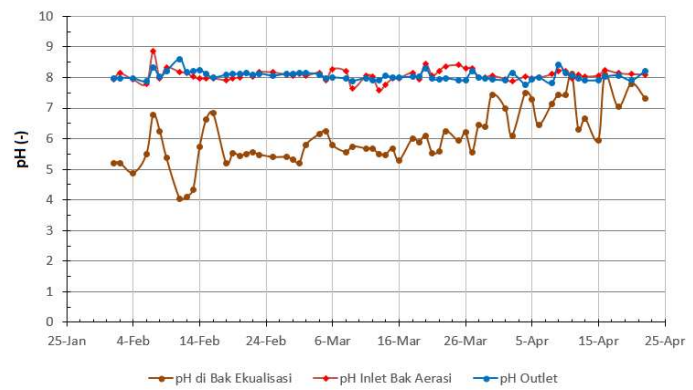

Gambar 10. Garfik pH Air Limbah di Bak Ekualisasi, pH Inlet Bak Aerasi dan Dan pH Outlet IPAL.

Proses menaikkan $\mathrm{pH}$ air air limbah tersebut perlu dilakukan sebab jika $\mathrm{pH}$ air limbah rendah reaksi fermentasi nata masih berlanjut di bak pemisah lemak maupun di bak ekualisasi, sehingga terjadi endapan partikel nata seperti jeli. Hal ini juga terjadi pada air limbah sisa fermentasi nata, yang jika ditampung dalam waktu yang lama akan terjadi endapan partikel nata berwarna putih seperti terlihat pada Gambar 11.

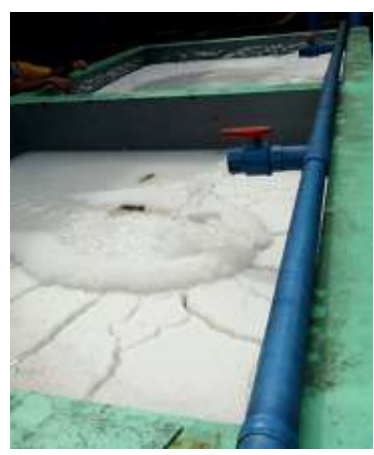

Gambar 11. Endapan yang terjadi dari air limbah panen (Sisa Fermentasi Nata) setelah ditampung di dalam Bak Penampung.

Aktivitas pembentukan nata oleh bacteri acetobacter xylinum mencapai kondisi optimum pada pH 4 (Novianti, 2003), oleh karena itu jika air limbah dari proses pembuatan Nata de Coco tidak dinaikkan maka reaksi pembentukan nata masih mungkin terjadi.

\subsection{Penyisihan Zat Organik}

Selama uji kienerja IPAL, konsentrasi COD di dalam air limbah berkisar antara 1460 $5175 \mathrm{mg} / \mathrm{l}$. Dari hasil pemerikasan di Laboratorium, dapat diketahui perbandingan BOD: COD sekitar 0,34 (Tabel 3). Hal ini menunjukkan bahwa air limbah limbah industri Nata de Colo relatif sulit diolah secara biologi dibandingkan dengan air limbah domestik yang perbandingan BOD : COD berkisar antara 0,4 0,8 (Metcalf and Eddy, 1991). Jika rasio BOD/COD kurang dari 0,5 itu berarti air imbah sulit untuk diurai secara biologis, sehingga membutuhkan pretreatment sebelum diolah dengan proses biologis. Atau melakukan pemilihan teknologi yang sesuai sebagai pasca pengolahan air limbah yang diolah secara biologis (Tiwari, 2013).

Pada perioda Pebruari merupakan tahapan penumbuhan mikroba di dalam sistem lumpur aktif. Air limbah industri Nata de Cono mempunyai konsentrasi COD yang tinggi, sedangkan konsentrasi Total Pospor $(P)$ rendah. Dari hasil pemeriksaan kualitas air limbah pada bulan April 2019, konsentrasi COD 997 mg/l, Amoniak 0,52 mg/l dan konsentrasi Total Pospor $0,23 \mathrm{ng} / \mathrm{l}$. Pada Uji kinerja perioda bulan Pebruari di tambahkan larutan nutrient dan mikroba yang terdiri dari campuran gula, tapioka, pupuk NPK, Sulfur, urea dan EM4 ke dalam bak aerasi sebanyak 320-400 liter per hari ( 8-10 jurigen @ 40 liter). Hal ini dilakukan untuk menaikan komposisi Unsur N dan P di dalam air limbah agar pertumbuhan mikroba menjadi lebih optimal. Untuk perbandingn Unsur $\mathrm{C}: \mathrm{N}: \mathrm{P}$ di dalam proses lumpur aktif yang ideal adalah 100 : 5 : 1 (Bitton, 1984).

Hasil uji kinerja IPAL perioda bulan Pebruari secara dapat dilihat pada Tabel 1. Dari hasil tersebut dapat dilihat konsentrasi COD di dalam air limbah sangat berfluktuasi berkisar antara $1.530-4.725 \mathrm{mg} / \mathrm{l}$, dengan konsentrasi rata-rata $3.387,5 \mathrm{mg} / \mathrm{l}$.

Tabel 1. Uji kinerja bulan februari 2019.

\begin{tabular}{lccccc}
\hline Tanggal & $\begin{array}{c}\text { COD } \\
\text { Inlet } \\
\text { (mgl) })\end{array}$ & $\begin{array}{c}\text { COD } \\
\text { Outlet } \\
\text { (mgl) })\end{array}$ & $\begin{array}{c}\text { Debit } \\
\text { (m/hari) }\end{array}$ & $\begin{array}{c}\text { Efisiensi } \\
\text { Penyisihan } \\
\text { COD (\%) }\end{array}$ & $\begin{array}{c}\text { COD } \\
\text { Loading } \\
\text { (Kg/m.h.hri) }\end{array}$ \\
\hline 1-Feb & 3615 & 2525 & 86 & 30,15 & 0,81 \\
2-Feb & 3250 & 2495 & 91 & 23,23 & 0,77 \\
4-Feb & 5175 & 2060 & 77 & 60,19 & 1,04 \\
6-Feb & 1850 & 1520 & 79 & 17,84 & 0,38 \\
7-Feb & 1530 & 685 & 101 & 55,23 & 0,40 \\
8-Feb & 1650 & 645 & 107 & 60,91 & 0,46 \\
9-Feb & 4725 & 760 & 52 & 83,92 & 0,64 \\
11-Feb & 2950 & 450 & 46 & 84,75 & 0,36 \\
12-Feb & 4885 & 385 & 43 & 92,12 & 0,55 \\
13-Feb & 4230 & 495 & 49 & 88,30 & 0,54 \\
14-Feb & 4280 & 540 & 52 & 87,38 & 0,58 \\
15-Feb & 4005 & 790 & 54 & 80,27 & 0,57 \\
16-Feb & 2815 & 780 & 78 & 72,29 & 0,57 \\
18-Feb & 3420 & 580 & 55 & 83,04 & 0,49 \\
19-Feb & 4075 & 425 & 59 & 89,57 & 0,63 \\
20-Feb & 4455 & 300 & 66 & 93,27 & 0,77 \\
21-Feb & 2805 & 315 & 63 & 88,77 & 0,46 \\
22-Feb & 2565 & 215 & 49 & 91,62 & 0,33 \\
23-Feb & 3045 & 135 & 46 & 95,57 & 0,37 \\
25-Feb & 3060 & 270 & 53 & 91,18 & 0,42 \\
27-Feb & 3080 & 260 & 63 & 91,56 & 0,51 \\
28-Feb & 3060 & 85 & 78 & 97,22 & 0,62 \\
\hline Rata- & & & & & \\
Rata & 3387,5 & 759,8 & 65,8 & 75,4 & 0,56 \\
\hline & & & & &
\end{tabular}


Konsentrasi COD air olahan (oulet IPAL) pada awal uji kinerja masih tinggi dan berangsurangsur turun dengan signifikan. Konsentrasi COD air olahan berkisar antara 85- 2525 mg/l, atau rata-rata $759,8 \mathrm{mg} / \mathrm{l}$. Efisiensi penyisihan COD berkiar antara 23,23 - 97,22 \%, atau ratarata $75,5 \%$. Debit air limbah juga berflukuasi berkisar antara $43-107 \mathrm{~m}^{3} /$ hari, atau rata-rata $65,8 \mathrm{~m}^{3} /$ hari. Pada minggu terakhir bulan Pebruari 2019, efisiensi penyisihan COD sudah menjadi stabil yakni sudah di atas $90 \%$. Dari perhitungan beban COD dapat dilihat bahwa pada masa penumbuhan mikroba (seeding), dengan beban COD rata-rata $0,56 \mathrm{Kg} \mathrm{COD} / \mathrm{m}^{3}$ volume bak aerasi per hari didapatkan efisiensi penyisihan COD rata-rata $75,4 \%$.

Setelah perioda seeding, dan efisensi penyisihan atau penghilanagn COD relatif stabil, penambahan nutrient dan mikroba dikurangi, menjadi 120 -160 liter per hari (3-4 Jurigen @40 liter). Hasil uji kinerja IPAL perioda bulan 1 Maret - 22 April 2019 secara dapat dilihat pada Tabel 2.

Tabel 2. Uji kinerja bulan Maret- April 2019

\begin{tabular}{|c|c|c|c|c|c|}
\hline Tanggal & $\begin{array}{l}\text { COD } \\
\text { Inlet } \\
\text { (mg/i) }\end{array}$ & $\begin{array}{l}\text { COD } \\
\text { Outlet } \\
\text { (mgI) }\end{array}$ & $\begin{array}{c}\text { Debit } \\
\text { (m3/hari) }\end{array}$ & $\begin{array}{c}\text { Efisiensi } \\
\text { Penyisihan } \\
\operatorname{COD}(\%)\end{array}$ & $\begin{array}{c}\text { COD } \\
\text { Loading } \\
\text { (Kg/m².hari) }\end{array}$ \\
\hline 1-Mar & 3395 & 250 & 81 & 92,64 & 0,72 \\
\hline 2-Mar & 3500 & 230 & 76 & 93,43 & 0,70 \\
\hline 4-Mar & 2760 & 190 & 97 & 93,12 & 0,70 \\
\hline 5-Mar & 1545 & 100 & 93 & 93,53 & 0,38 \\
\hline 6-Mar & 2670 & 65 & 92 & 97,57 & 0,64 \\
\hline 8-Mar & 3715 & 275 & 97 & 92,60 & 0,94 \\
\hline 9-Mar & 3190 & 330 & 103 & 89,66 & 0,86 \\
\hline 11-Mar & 2865 & 390 & 103 & 86,39 & 0,77 \\
\hline 12-Mar & 3895 & 350 & 96 & 91,01 & 0,98 \\
\hline 13-Mar & 4385 & 210 & 86 & 95,21 & 0,99 \\
\hline 14-Mar & 3550 & 225 & 71 & 93,66 & 0,66 \\
\hline 15-Mar & 3035 & 370 & 77 & 87,81 & 0,61 \\
\hline 16-Mar & 2495 & 150 & 92 & 93,99 & 0,60 \\
\hline 18-Mar & 2555 & 145 & 102 & 94,32 & 0,68 \\
\hline 19-Mar & 1460 & 215 & 102 & 85,27 & 0,39 \\
\hline 20-Mar & 1090 & 195 & 104 & 82,11 & 0,30 \\
\hline 21-Mar & 2080 & 160 & 103 & 92,31 & 0,56 \\
\hline 22-Mar & 1985 & 305 & 59 & 84,63 & 0,31 \\
\hline 23-Mar & 1905 & 255 & 84 & 86,61 & 0,42 \\
\hline 25-Mar & 1885 & 290 & 87 & 84,62 & 0,43 \\
\hline 26-Mar & 2730 & 180 & 104 & 93,41 & 0,74 \\
\hline 27-Mar & 2875 & 155 & 133 & 94,61 & 1,00 \\
\hline 28-Mar & 3120 & 180 & 129 & 94,23 & 1,05 \\
\hline 29-Mar & 2160 & 170 & 98 & 92,13 & 0,55 \\
\hline 30-Mar & - & - & 121 & - & - \\
\hline 1-Apr & - & - & 68 & - & - \\
\hline 2-Apr & - & 135 & 123 & - & - \\
\hline 4-Apr & 1670 & 110 & 124 & 93,41 & 0,54 \\
\hline 5-Apr & 2890 & 215 & 67 & 92,56 & 0,51 \\
\hline 6-Apr & 1665 & 110 & 90 & 93,39 & 0,39 \\
\hline 8-Apr & 1660 & 55 & 59 & 96,69 & 0,26 \\
\hline 9-Apr & 1450 & 55 & 88 & 96,21 & 0,33 \\
\hline 10-Apr & 1680 & 30 & 102 & 98,21 & 0,45 \\
\hline 11-Apr & 1845 & 28 & 98 & 98,48 & 0,47 \\
\hline 12-Apr & 2020 & 26 & 120 & 98,71 & 0,63 \\
\hline 13-Apr & 1890 & 21 & 113 & 98,89 & 0,56 \\
\hline 15-Apr & 2475 & 32 & 86 & 98,71 & 0,56 \\
\hline 16-Apr & 2345 & 41 & 114 & 98,25 & 0,70 \\
\hline 18-Apr & 4270 & 48 & 58 & 98,88 & 0,65 \\
\hline 20-Apr & 2110 & 32 & 109 & 98,48 & 0,60 \\
\hline 22-Apr & 3720 & 38 & 115 & 98,98 & 1,12 \\
\hline $\begin{array}{l}\text { Rata- } \\
\text { Rata }\end{array}$ & 2540,4 & 163.1 & 95,7 & 93.3 & 0.625 \\
\hline
\end{tabular}

Pada perioda ini Debit air limbah yang masuk ke IPAL berkisar antara 58 - $133 \mathrm{~m}^{3} /$ hari, atau rata-rata 95,7 $\mathrm{m}^{3} /$ hari. Konsentrasi COD Inlet yang masuk ke IPAL lumpur aktif berkisar antara 1090 - $4385 \mathrm{mg} /$, atau rara-rata 3387,5 $\mathrm{mg} / \mathrm{l}$. Konsentrasi COD air olahan (Outlet) berkiasar antara 21 - $390 \mathrm{mg} / \mathrm{l}$, atau rata-rata $163,1 \mathrm{mg} / \mathrm{l}$. Efisiensi penyisihan atau penghilangan COD berkisar antara 82,11 $98,98 \%$, atau rata-rata $95,7 \%$. Dari hasil perhitungan (Tabel 2), dapat dilihat beban COD (COD Loading) yang masuk ke IPAL lumpur aktif berkisar antara 0,37 - 1,04 kg COD/m³ Vol. bak aerasi per hari, atau rata-rata $0,56 \mathrm{~kg}$ COD/ $\mathrm{m}^{3}$.hari. Dengan demikian dengan beban COD rata-rata $0,56 \mathrm{~kg} \quad \mathrm{COD} / \mathrm{m}^{3}$.hari didapatkan efisiensi penghilangan COD rata-rata sebesar 95,7 \%. Dilihat dari efisiensi penghilangan COD, maka kinerja IPAL lumpur aktif yang ada sudah sangat baik.

Permasalahannya adalah konsentrasi COD inlet sangat berfluktuasi sehingga jika konsentrasi COD inlet melebihi 3000 mg/l, maka dengan efisiensi penyisihan COD sebesar $95 \%$, maka kemungkinan konsentrasi COD air olahan akan melebihi baku mutu air limbah yakni 150 $\mathrm{mg} / \mathrm{l}$. Oleh karena itu sedapat mungkin konsentasi COD yang masuk ke IPAL lumpur aktif di atur lebih kecil dari 3000 mg/l dengan cara pengaturan pembuangan air limbah antara yang air limbah pekat dan air limbah encer.

Jika konsentrasi COD air limbah lebih tinggi dari $3000 \mathrm{mg} / \mathrm{l}$, agar hasil air olahan dpat memenuhi baku mutu, maka proses lumpur aktif memerlukan waktu kontak yang lebih lama atau dapat dikakukan dengan melakukan pengolahan lanjutan agar hasil air olahan selalu dapat memenuhi baku mutu yang diharapkan.

Garfik konsentrasi COD Inlet dan Outlet IPAL serta efisiensi penyisihan COD selama uji kinerja bulan Maret- April 2019 dapat dilihat pada Gambar 12, sedangkan garfik Konsentrasi COD Inlet dan Outlet IPAL serta debit air limbah dapat dilihat pada Gambar 13. Dari Gambar 13 tersebut pada saat proses lumpur dalam keadaan stabil, konsetrasi COD air lohan sudah memenuhi baku mutu air limbah yakni lebih kecil $150 \mathrm{mg} / \mathrm{l}$.

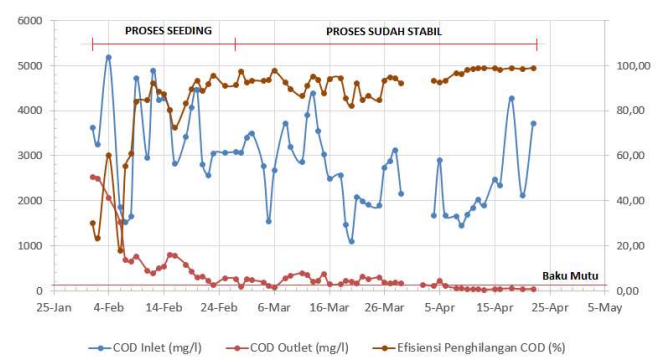

Gambar 12. Garfik konsentrasi COD Inlet dan Outlet IPAL serta efisiensi penyisihan COD. 


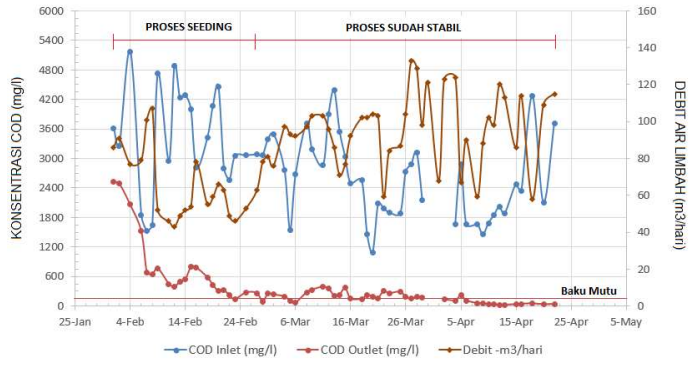

Gambar 13. Garfik konsentrasi COD Inlet dan Outlet IPAL serta debit air limbah

Dari hasil pemeriksaan kualitas air limbah sebelum dan sesudah diolah dengan IPAL lumpur aktif pada Tanggal 1 April 2019, dapat dilihat pada Tabel 3. Dari tabel tersebut dapat dilihat bahwa konsentrasi COD di dalam air limbah (COD Inlet) adalah $2141 \mathrm{mg} / \mathrm{l}$, dan setelah melalui proses pengolahan di dalam IPAL lumpur aktif turun menjadi $98 \mathrm{mg} / \mathrm{l}$. Konsentrasi BOD inlet $722 \mathrm{mg} / \mathrm{l}$ dan setelah pengolahan turun menjadi $30 \mathrm{mg} / \mathrm{l}$, sedangkan konsentrasi TSS inlet $250 \mathrm{mg} / \mathrm{l}$ dan setelah pengolahan turun menjadi $13 \mathrm{mg} / \mathrm{l} . \mathrm{pH}$ air limbah sebelum diolah 5,18 dan setelah pengolahan naik menjadi 8,11. Dengan demikian hasil air olahan sudah memenuhi baku mutu sesuai dengan Peraturan Menteri Lingkungan Hidup Republik Indonesia Nomor 5 Tahun 2014 Tentang Baku Mutu Air Limbah : Lampiran XVII Baku Mutu Air Limbah Bagi Usaha Dan/Atau Kegiatan Pengolahan Kelapa, maka baku mutu air limbah industri Nata de Coco yang boleh dibuang ke badan air atau saluran umum yakni konsentrasi maksimum COD $150 \mathrm{mg} / \mathrm{l}$, BOD 75 $\mathrm{mg} / \mathrm{l}$, TSS $100 \mathrm{mg} / \mathrm{l}$ dan $\mathrm{pH}$ 6-9. Penampakan fisik air limbah sebelum diolah, air limbah di bak aerasi dan air olahan dapat dilihat seprti pada Gambar 14.

Tabel 3. Hasil Analisa Kualitas Air Limbah Sebelum Dan Sesudah Pengolahan (IPAL Lumpur Aktif).

\begin{tabular}{|c|c|c|c|c|}
\hline No & PARAMETER & UNIT & $\begin{array}{l}\text { COD } \\
\text { INLET }\end{array}$ & $\begin{array}{c}\text { COD } \\
\text { OUTLET }\end{array}$ \\
\hline 1 & BOD & $\mathrm{mg} / \mathrm{l}$ & 722 & 30 \\
\hline 2 & COD & $\mathrm{mg} / \mathrm{l}$ & 2141 & 98 \\
\hline 3 & $\begin{array}{l}\text { Total } \\
\text { Dissolved } \\
\text { Solids, TDS }\end{array}$ & $\mathrm{mg} / \mathrm{l}$ & 624 & 1280 \\
\hline 4 & $\begin{array}{l}\text { Total } \\
\text { Suspended } \\
\text { Solids, TSS }\end{array}$ & $\mathrm{mg} / \mathrm{l}$ & 250 & 13 \\
\hline 5 & $\begin{array}{l}\text { Oil and } \\
\text { Grease }\end{array}$ & $\mathrm{mg} / \mathrm{l}$ & $<0,14$ & 0,51 \\
\hline 8 & $\mathrm{pH}$ & - & 5,18 & 8,11 \\
\hline
\end{tabular}

Tgl Sampling: 1 April 2019.

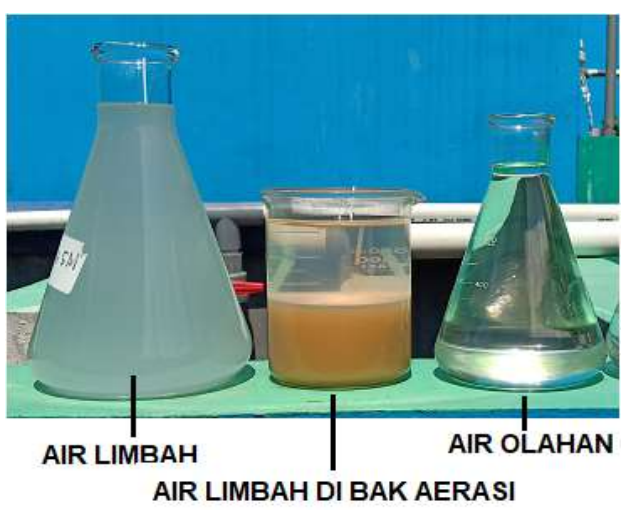

Gambar 14. Penampakan fisik air limbah sebelum diolah, air limbah di bak aerasi dan air olahan.

\section{KESIMPULAN}

Dari hasil penelitaian tersebut di atas dapat disimpulkan:

a. Air limbah industri Nata de Coco mempunyai $\mathrm{pH}$ yang rendah dengan konsentrasi zat organik (COD) yang tinggi, dapat mencapai lebih dari $5000 \mathrm{mg} / \mathrm{l}$, serta sangat berfluktuasi.

b. Perbandingan BOD/COD berkisar 0,34 sehingga relatif sulit untuk terurai secara biologis.

c. Untuk mengolahan air limbah industri Nata de Coco dengan menggunakan proses lumpur aktif, $\mathrm{pH}$ air perlu dinaikan menjadi sekitar 8 agar proses lumpur aktif berjalan optimal.

d. Dengan beban COD rata-rata $0,56 \mathrm{~kg}$ $\mathrm{COD} / \mathrm{m}^{3}$.hari didapatkan efisiensi penghilangan COD rata-rata sebesar 95,7 $\%$.

\section{PERSANTUNAN}

Penulis menyampaikan terima kasih kepada Pimpinan Perusahaan PT. Kara Santan Pratama atas bantuan dan fasilitasinya dalam melakukan kajian penelitian ini. Terimakasih juga disampaikan kepada Bapak Anung dan Bapak Hafzialman yang telah mendukung terlaksananya kegiatan ini.

\section{DAFTAR PUSTAKA}

1. Alaban, C.A. 1962. Studies On Optimum Conditions For Nata de Coco Bacterium or Nata Formation in Coconut Water. Philippine Agric. 96(2)490-515.

2. Bhargava, Akshey. 2016. Activated Sludge Treatment Process - Concept and System Design. IJEDR Volume 4, Issue 2. ISSN: 2321-9939 
3. Bitton G. (1994). "Wastewater Microbiology". Wiley-Liss, New York.

4. Chudoba, J. 1989. Activated SludgeBulking Control, pp. 171-202, in Encylopedia of Environmental Control Technology, Vol. 3, Wastewater Treatment Technology, P.N. Cheremisinoff, Ed. Gulf Publishing Co., Houston, TX.

5. Curds, C.R., and H.A. Hawkes, 1983. Eds. 1983. Ecological Aspects of Used Water Treadment, Vol. 2, Academic, London.

6. Davis, M.L., and D.A. Cornwell. 1985. Introduction to Environmental Engineering. PWS Engineering, Boston.

7. Ebie Kunio and Ashidate Noriatsu. 1992. " Eisei Kougaku Enshu - Jousuidou To Gesuidou", Morikita Publishing, Tokyo, Japan (1992).

8. Forster, C. F., and D. W. M. Johnston. 1987. Aerobic Processes, pp. 15-56. In: Environmental Biotechnology, C.F. Forster and D.A J. Wase, Eds. Ellis Horwood, Chichester, U.K.

9. Gaudy, A.F.Jr. and E.T. Gaudy.1988. Elements of Bioenvironmental Engineering. Engineering Press, San Yose. CA.

10. Hakimi, Rini dan Daddy Budiman. 2006. Aplikasi Produksi Bersih (Cleaner Production) pada Industri Nata De Coco. Jurnal Teknik Mesin. Vol 3 (2) hal: 90-98.

11. Hammer, M.J. 1986. Water and Waste Water Technology. Wiley, New York.

12. JSWA, 1984. "Gesuidou Shissetsu Sekkei Shisin to Kaisetsu ", Nihon Gesuidou Kyoukai, Japan.

13. Metcalf and Eddy (1991), Wastewater Engineering: Treatment Disposal, Reuse, 3rd ed., G. Tchobano-glous and F.L. Burton, eds., McGraw-Hill, Toronto.

14. Nathanson, J.A., 1986. Basic Environmental Technology: water Supply, Waste Disposal and Pollution Control. Wiley, New York.

15. Nelson, P.O., and A.W. Lawrence. 1980. Microbial Viability Measurements and Activated Sludge Kinetics. Water Research 14: 217-225.

16. Novianti dan Hendrizon, 2003. Pembuatan Nata de Soya dari Limbah Cair Pabrik Tahu, Teknik Kimia Universitas Sriwijaya, hal. 9-19

17. Pambayun, R, 2002, Teknologi Pengolahan Nata De Coco, Yogyakarta: Kanisius.

18. Peraturan Menteri Lingkungan Hidup Republik Indonesia Nomor 5 Tahun 2014 Tentang Baku Mutu Air Limbah.

19. Rainier Hreiz, M.A. Latifia, Nicolas Rocheb. 2015. Optimal design and operation of activated sludgeprocesses: State-of-the- art, Chemical Engineering Journal. Volume 281, 1 December 2015, Pages 900-920

20. Saragih, Y.P. 2004. Membuat Nata de Coco. Jakarta: Puspa Swara.

21. Sterrit. R.M. dan Lester.J.N. 1988. "Microbiology for Environmental and Public Health Engineers", E.\& F.N Spon Ltd, London.

22. Suhardiyono, L., 1988. Tanaman Kelapa Budidaya dan Pemanfaatannya. Jogyakarta: Kanisius.

23. Tiwari, Amit Kumar. 2013. Combination of Theoretical and Practical Approach to Design an Activated Sludge Process (ASP) and Selection of Other Treatment Technologies with ASP for Effluent of API Manufacturing Industry. International Journal of Advanced Research and Technology (2013), Volume 1, Issue 2, 6775

24. U.S. EPA, 1987. The Causes and Control Activated of Activated Sludge Bulking and Foaming. EPA-625/8-87/012, Cincinnati, $\mathrm{OH}$.

25. Verstraete, W., and E. van Vaerenbergh. 1986. Aerobic Activated Sludge, pp.43-112, In: Biotechnology, H.J. Rehm and G. Reed Eds.; Vol. 8. 